\title{
Magical Realism, Spiritual Realism, and Ecological Awareness in Linda Hogan's People of the Whale
}

\section{François Gavillon}

\section{(2) OpenEdition}

Electronic version

URL: http://journals.openedition.org/elohi/602

DOI: $10.4000 /$ elohi.602

ISSN: 2268-5243

\section{Publisher}

Presses universitaires de Bordeaux

\section{Printed version}

Date of publication: 1 January 2013

Number of pages: $41-56$

ISBN: 978-2-86781-899-8

ISSN: 2431-8175

\section{Electronic reference}

François Gavillon, « Magical Realism, Spiritual Realism, and Ecological Awareness in Linda Hogan's People of the Whale », ELOHI [Online], 3 | 2013, Online since 01 January 2014, connection on 01 May 2019. URL : http://journals.openedition.org/elohi/602 ; DOI : 10.4000/elohi.602 


\section{Magical Realism, Spiritual Realism, and Ecological Awareness in Linda Hogan's People of the Whale}

Native American peoples are traditionally seen as being engaged in a dialogic relationship with the natural world, a world they do not perceive as an inanimate "out-there" but as a close relative, Mother Earth, whose inhabitants are all partners in life ${ }^{1}$. Typically, the relationship is one of respect and reciprocity, but tradition is sometimes flouted. Linda Hogan's latest novel, People of the Whale (2008) is in part a poetic envisionment of cultural alienation, ecological transgression and consequent natural retaliation: when the traditional ecology of give-and-take is violated by some of the A'atsika people, nature has its own way of talking back. Tsunami, fire, volcanic eruption, and more prominently drought, are nature's responses to human offenses.

Hogan experimented with historical fiction with her first novel, Mean Spirit (1990). Set in Osage Indian territory in Oklahoma in the 1920s, the novel tells a story of violence, crime, and callous despoliation as oil is discovered on Native lands. Already noticeable is the blend of historical material and supernatural elements-physiological alterations, natural and meteorological aberrations, two dead bodies rising from their graves, "in a continuing parallel with the crucifixion and resurrection of Christ" (Casteel 62) -, characteristic of Hogan's fictions. As in People of the whale, female protagonists are central: grandmother, mother and daughter Lila, Grace and Nola Blanket incarnate the novel's moral, spiritual, and environmental ethics.

The action of Solar Storms, published in 1995, is set in the boundary waters between Canada and Minnesota. It is also a story of women, with seventeenyear-old protagonist and narrator Angel (Angela Jensen) returning to the land of her childhood and reconnecting with her female relatives-and with herself. It is a tale of heritage and coming-of-age, communality and individuality, but the novel also dramatizes the spiritual and physical bonds that unite the

1. Or "fellows in mortality" as philosopher Cora Diamond puts it (2004: 102). 
characters and their land. Symbolically, Angel's scarred face embodies the disfiguration of ancestral lands. In Hogan's fictions, environmental devastation characteristically parallels cultural disempowerment. The possibility of personal, communal and environmental healing is adumbrated when Angel sets out to fight the hydroelectric dam project that threatens to flood the area. ${ }^{2}$

Power, Hogan's third fiction (1998), takes the reader to the Native homeland of the Taiga people of southern Florida. The story is told by sixteen-year-old Omishto whose divided allegiance to Euro-American culture and tribal culture is one of the loci of power conflicts that the novel fictionalizes. The dwindling of the Taiga is paralleled by the diminishing of wild habitats and the endangerment of one of their iconic animals, the Florida panther. In this other coming-of-age tale, two climactic events cause Omishto's life to shift course: a hurricane of inordinate proportion cuts her from her familiar world; she witnesses her aunt Ama kill a panther, the sacred animal believed to be the ancestor of the Taiga people. From then on, Omishto tunes in to yet unexperienced realities, slowly awakening to the magic and sanctity of nature. For Amy Greenwood Baria, the novel opens on a "near suspension of reality" which "prefigures the alternative world" that Omishto will experience:

Omishto's isolation with Ama in the woods sets up the conflict of the novel by emphasizing its duality: the older, natural world and the outside, civilized world. And, although Omishto initially dismisses the idea of magic [...] her posthurricane experience with Ama and the Florida panther will alter the way she evaluates reality, allowing her the freedom to accept the magical as part of her Native culture. (Greenwood Baria 68)

People of the Whale is set among the A'atsika people of the Northwest, focusing on one seaside village, Dark River, where for thousands of years there has been-or used to be, that is the question-a particularly strong spiritual relationship with the sea and its inhabitants, especially the octopus and the whale. Although the setting of People of the Whale, is diametrically opposed to the geography of Power, thematic similarities with the previous novels are visible such as the spiritual connection between Native peoples (the elders, in particular) and sacred animals, rootedness in ancestral lands, problematic coexistence of tradition and modernity. Recurrent formal devices include central female narratorial and/or dramatic agency, and the admission of

2. On the notions of femininity, origin and naming in Solar Storms, see Geoffrey Stacks' "A Defiant Cartography: Linda Hogan's Solar Storms." The essay postulates that Hogan's novel offers a critique of embodied geography and land-as-feminine, colonizing mapping. 
apparently supernatural elements in an otherwise realistic narrative-which is the simplest definition of magical realism. ${ }^{3}$

Is "magic realism" the best term to describe Hogan's fiction? This is the first question that this study means to answer. We shall then see that Hogan's special brand of realism proves a powerful tool to displace habitual oppositions (man $v$. nature) and expose anthropological-social (male $v$. female), historical-political (Euro-American $v$. Native-American), and ecological (respectful whalehunting $v$. blind killing) unbalance. Finally, we shall show that by challenging standard polarities, Hogan's uncanny realism effectively promotes the agency and loquacity of nature, and fosters a more empathetic form of reader's response, ultimately conducive to ecological awareness and care.

At first glance, Hogan's People of the whale, with its blend of realism and magic occurrences, presents apparent similarities with fictions described as magic realist. In their valuable collection of essays, Magical Realism: Theory, History and Community (1995), co-editors Lois Parkinson Zamora and Wendy B. Faris identify several cultural elements which contribute to the characteristically defamiliarizing aspect of magical realism. Texts labeled magical realist, they say, often draw upon

non-Western cultural systems that privilege mystery over empiricism, empathy over technology, tradition over innovation. Their primary narrative investment may be in myths, legends, rituals - that is, in collective (sometimes oral and performative, as well as written) practices that bind communities together. (Zamora, Faris 3)

In her own essay, "Scheherazade's Children," (163-190) Wendy Faris lists five other elements: 1) the text contains an irreducible element of magic, 2) descriptions detail a strong presence of the phenomenal world, 3) the text invites contradictory understandings, thus arousing readerly hesitation and doubt, 4) the reader experiences the closeness or near-merging of two realms, one realist, the other magical, 5) the text redefines notions of time, space, and identity. Let us first examine whether People of the Whale aligns with the criteria recognized by Zamora and Faris.

3. I am using the term "magical realism" in the sense it has been used since the 1950s, in relation to Latin American literature mostly, i.e., denoting the presence of magical elements in an otherwise realist narrative, or "the commingling of the improbable and the mundane," to use Salman Rushdie's words in Midnight's Children. 
Who are the A'atsika? Where exactly does the action take place and when? To begin with, the A'atsika are a fictional tribe, one among "the paddling nations," a beautiful albeit vague denomination. The reserve and village where the story takes place are never clearly located. In fact, the narrator takes pains to cover the tracks: "It is a secret place, this world. You could say it is in Washington but that is too far north, by degrees and fathoms. I keep it a secret, the place, the people, though the world will soon hear about it" (Prologue 10-11). ${ }^{4}$

Defamiliarization also occurs because of the presence of "irreducible magic." Several villagers are endowed with special powers as well as uncanny physical features. The main characters are, in fact, marked out for special fortunes: Witka, the grandfather, can stay under water for long times and "converse" (10) with the whales; his wife Mary (her Catholic name) can communicate with him across land, air and water:

And then together, when he saw a whale, the two of them pleaded and spoke. Look how we are suffering. Take pity on us. Our people are small. We are hungry.

It was said the whale listened mostly to the woman because who could ignore her pleading, singing, beautiful voice? (21)

Ruth, the heroine, is a tall girl, "[1]arge in spirit, strong in hand, big in heart" (27). She, too, is marked out for the sea:

As an infant, Ruth was born with gill slits. It had happened before, children being born with gills, but her mother Aurora, said "It's an omen. I don't know what, but I don't like it. She's bound for water, this one, Like her father." [...] The midwife had to keep the baby in a zinc tub filled with water so she wouldn't drown in air before they took her to a doctor in town. The gills were right in front of her ears. The doctors were baffled and it took many weeks to sew the gills together and keep Ruth Small breathing through her lungs. Later it seemed she heard things others didn't. She heard through water, schools of fish and the whales before they surfaced. (27)

Her son Marco, likewise, is "bound for water":

When he was born, Marco swam out of the birth canal hands first, like a diver. [...] Ruth looked at every part of him, his perfect brown fingers. Then his toes. She laughed. "Well, no wonder, Doctor! Mother, look, he has some webbed toes!

4. It is no secret, however, that the fictional A'atsika were modeled after the Makah people of the Pacific Northwest. For clear evidence of the parallel between facts and fiction, see for instance Hogan's 1996 Seattle Times article, "Silencing Tribal Grandmothers: Traditions, Old Values At Heart Of Makah's Clash Over Whaling," or Summer Harrison's “Sea Level: An Interview with Linda Hogan.” 
Of course he came out swimming." Webbed feet were not unknown around those parts, but no one liked to admit it. [...] They were a family not bound to land, that was for sure [...]. Like the whales who were dependent on land, in many ways they lived in two elements. (33-34)

Elders, in particular, can show unusual aptitudes like communicating the old way, without exchanging words; they know how to sing the ocean and fish into propitious dispositions; they can stop fires and volcano lava, should nature speak in a catastrophic voice. Respect for the natural world, humility, faith characterize the elders, "the traditionalists" as the text calls them without contempt, who live across the bay, in the whitewashed houses, and still live, pray and teach the traditional way. Conversely, the younger generation is depicted as a lost generation. Many, particularly those who fought in Vietnam, have gone off course. Thomas, Ruth's husband and Marco's father, is one of them, too deep into his lies, guilt, and trauma to be able to reconnect with his kin and his people.

Tribal lore, traditions are endowed with special brilliance as only the rustic ways seem to celebrate and show respect for the natural environment that has sustained the tribe for so long. The phenomenal world is everywhere present. Nature manifests itself in its elemental beauty and force throughout the novel: in the volcanic rocks and blue sea of A'atsika country, in the brown paddies and green forests of Vietnam. This is how the novel begins:

We live on the ocean. The ocean is a great being. The tribe has songs about the ocean, songs to the ocean. It is a place where people's eyes move horizontally because they watch the long, wide sea flow into infinity. Their eyes follow the width and length of the world. Black rocks rise out of the ocean here and there, lending themselves to stories of sea monsters that might have consumed mere mortals. Several islands along the coast are tree-covered green jewels. (9)

We notice that the opening lines involve nature and humans as well as stories, and recognize nature as a living being. Common distinctions have already started to blur although nature is affirmed in its formidable presence.

The animal world is overwhelmingly present, too-animals of the sea mostly (but not exclusively): fish, whale, octopus. The day before Thomas was born, the whole village could see an octopus walk out the sea on all eight legs and take residence in a nearby cave. Although the word "trickster" is never mentioned in the novel, one reads of "shape-shifters and their deceits and witchery on humans" (17). As we shall see, the octopus plays a central part in the development of the plot.

The whale is obviously a highly determined animal figure in American literature. In the novel, it is synonymous with past and tradition (in A'atsika 
belief, a whale birthed the Aatsika people); it is also a metaphor for ecological harmony between human lifeways and the life of nature. The whale stands for time and place, immemorial time and universal place:

He remembers when the whales used to pass by in great numbers. He would watch one, its great shining side, the eye with its old intelligence, the gentleness of it in the body covered with barnacle life and creatures. It was loved by his people. It was a planet. When they killed it, he thinks perhaps they killed a planet in its universe of water. (267)

Animals do not solely function as allegorical motifs in the vindication of ecological balance, they are also, and primarily, physical creatures, spiritual partners, whose living presence need be acknowledged and defended. Nowhere in the text do we find prolonged instances of ironic distance between the narrator's voice and the characters' perceptions and emotions. Hogan's vindication of indigenous ecology is implicit in her protagonist's spiritual connection to the other-than-human world around her. This is perhaps where a dividing line can, and should, be drawn between, say, Gabriel Garcia Márquez-whom Hogan acknowledges as an author she read and learned from (Harrison 164) - , whose magical realist texts are pervaded by narratorial irony, and Hogan's fiction, whole-heartedly attentive to mysterious realities and adherent to a non-Western mode of being-in-the-world. In her 1985 landmark study, Magical Realism and the Fantastic: Resolved Versus Unresolved Antinomy, Amaryll Chanady scrutinized magical realism in the light, not of cultural studies, but of the developments of structural poetics and narratology. The chief merit of her essay is to successfully define magical realism as a literary mode with specific narratological and modal aspects. One important modal characteristic is that

The author of a magico-realist narrative [...] implicitly presents the irrational world view as different from his own by situating the story in present-day reality, using learned expressions and vocabulary, and showing he is familiar with logical reasoning and empirical knowledge. The term "magic" refers to the fact that the perspective presented by the text in an explicit manner is not accepted according to the implicit world view of the educated implied author. (Chanady 1985: 22)

Although People of the whale is set in its own "present-day reality," a pedestrian world of modular houses and styrofoam coffee cups, coke machines and Johnnie-Cash haircuts, one never feels the "authorial reticence" that Chanady 
sees as constitutive of the magico-realist mode. ${ }^{5}$ Like the young heroines of Solar Storms and Power, Hogan is also in a mediating position between two worlds and two cultures. ${ }^{6}$ Mediation does not accord with ironic aloofness, however; it means implication and sincerity. For Jonathan Steinwand, Hogan's protagonists are "[m]arginalized and indigenous peoples," "liminal figures negotiating the boundaries of the dominant "civilization" and wild nature, of traditional premodern and postmodern late capitalist life-styles" (Steinwand 184). But more importantly

The novelists themselves negotiate their liminal positions as cosmopolitan global cultural ambassadors with specific connections that allow them access to the lives of the insiders who dwell more permanently in the locales. Their audiences also include cosmopolitan readers lured by the postcolonial and the ecopastoral exotic. (Steinwand 185$)^{7}$

In the face of engaged authorial negotiation and narratorial adherence to plot and characters, one can hardly describe Hogan's novels as magical realist texts. Examining what he saw was a major innovative aesthetic strategy in the

5. It is interesting, however, that Zamora and Faris's acception of magical realism should point to thematic, and perhaps cultural and political, orientations that also characterize People of the Whale: "[...] magical realism may be considered an extension of realism in its concern with the nature of reality and its representations, at the same time that it resists the basic assumptions of post-enlightenment rationalism and literary realism. Mind and body, spirit and matter, life and death, real and imaginary, self and other, male and female: these are boundaries to be erased, transgressed, blurred, brought together, or otherwise fundamentally refashioned in magical realist texts" (Zamora, Faris 6).

6. Angel and Omishto can be seen as partly autobiographical reminiscences of Hogan's own childhood and adolescent years, uncomfortably wedged in between two worlds: "And then I started writing about my childhood because I was in Washington, D.C. I lived in Maryland and suddenly Oklahoma seemed so far away. And it seemed likehere was this kid who had grown up and her family had a horse and wagon, and she had an outhouse and no electricity and no water, and suddenly I'm going to the Kennedy Center" (Harrison 163).

7. Joni Adamson remarks that Hogan is an experienced ethnoscientist and gray whale ethologist, which is evidence for her that "Ruth's prayers do not imply that she is superstitious or given to fantasy. She believes in the 'world of matter' and as a lifelong fisherwoman, she understands marine biology" (Adamson 158). "Ruth's prayers invite all the people and nations of the Earth to extend their temporal gaze so that they might see, as if through the eye of the octopus, the multiple relationships among living organisms and species that have a right to maintain and regenerate life cycles and evolutionary processes" (Adamson 159). 
novels of writers Edna Escamill, Kiana Davenport and Linda Hogan, Patrick Murphy dismissed the label "magical realism" and suggested another term, more indicative of these novelists' spiritual implication: "spiritual realism."

The spirituality these women authors represent, like their sense of ecological responsibility and their inhabitational orientation, forms part of an alternative reality, which in the long haul will prove to be far less illusory than what passes for realistic in the current ecosuicidal milieu of transnational consumptionist culture. (Murphy 10)

Mean Spirit and Solar Storms are examples of fictions whose "major female characters engage in spiritual practices that connect them with a more-thanvisual reality of interconnectedness among people, other animals, plants, environments, and the land itself" (Murphy 9). The same can be said of People of the Whale, with Ruth, Marco, and the elders engaging in other-than-intellectual interaction with their human and non-human environments. Insistence on the phenomenal world, reliance on non-Western modes of being-in-the world, ecological interdependency and spiritual connection with the other-thanhuman world are salient features of Hogan's spiritual realist prose.

Magical realism and spiritual realism may converge on common thematic and political grounds. Often visible in both literary modes is the propinquity between the historical and the imaginary. What does Hogan's spiritual realism does to/ with history, to/with culture, to/with gender? Zamora and Faris underline the potential of magical realism as both disrupting and enlightening force:

Magical realist texts are subversive: their in-betweenness, their all-at-onceness encourages resistance to monolithic political and cultural structures, a feature that has made the mode particularly useful to postcolonial cultures and, increasingly, to women. Hallucinatory scenes and events, fantastic/phantasmagoric characters are used [...] to indict recent political and cultural perversions. History is inscribed, often in detail, but in such a way that actual events and existing

8. For Murphy, spiritual realism "seeks to represent a sense of ecological responsibility to a referentially recognized material more-than-human world on the part of its characters and the need for the adoption of such a sensibility on the part of its readers. It articulates an alternative way of viewing reality and often promotes or defends alternative lifestyles, community formations, and economic practices. And, particularly when practiced by U.S. writers of color, it is often represented as explicitly arising from a history and wisdom of inhabitation, either indigenous or native to place" (Murphy 6). 
institutions are not always priviliged and are certainly not limiting: historical narrative is no longer chronicle but clairvoyance. (Zamora, Faris 6)

In its own spiritual realist mode, People of the Whale powerfully exposes political, social, racial, environmental injustices. Part of the action takes place in Vietnam, sometime in the late sixties or early seventies (again time markers are wanting), which allows haunting descriptions of wartime atrocities. The war is a dehumanizing experience for Thomas and his friends.

He had been watching keenly the split in the human heart, including his own. He took to the airfield and with orders to report to one of the worst places in the world. When they arrived he found himself seeing a river of blood and he was sick with it and the smell of gas, napalm with its ceaseless burning. God created it and what kind of a creature was this god, and he was afraid at first, then he hated, and then he was no longer Thomas. Monster. That's what he was with brother M16 and AK and grenades. (175)

The smell of "human flesh, chemical, smoke, cordite, napalm, fear" (170171) is always with him. The other men in his outfit have become killers and rapists of women and children. When they try to set fire to rice paddies that won't burn, they contaminate them with chemicals. Entire forests are burned down. War destroys nature as much as it destroys human beings.

The analepses that revisit Thomas's Vietnam experience bear witness to modern history, but Hogan's novel is also an indictment of political cynicism and folly, past and present:

Watching the bullets, the men surviving fire, the dying children, what the women saw on television gave them some truth and from then on American wars were not on the television because people would rise up against their own government if they saw what they had done.

Then the back of this world, all across the land, began to break. Ruth herself heard the sound of its breaking, almost inaudible, but she could hear it, for her ears could even hear the fish and the whales. Hearing the country break, she knew nothing would ever be the same. (53)

Ruth and Marco still experience the old-time spiritual contact with the nonhuman world, the way their ancestors did. By contrast, Dwight and his clique represent acculturation, hypocrisy, violence, and greed. Dark River's tribal council has covertly decided to end the moratorium on whale-killing and have their whale-hunt. The tribe has not been consulted, the elders and women have been excluded from the talks and the negotiations to sell the meat and fat to Japan have been kept a secret. Ruth and her mother, who oppose the hunt, are looked upon with suspicion and hostility. Aurora's house is broken into, Ruth's 
boat is ransacked, her dog is killed. People of the Whale is also a story of women, women of courage and resilience: Mary, Linda, Wilma, and also Lin, Thomas's daughter. At the center of the social and diegetic web is Thomas's abandoned wife, Ruth, "a woman who could stand alone in the world," (30) whom the text likens less to the biblical figure than to an unsung Penelope. This is how the chapter entitled "The Wife of Marco Polo" begins:

No one wrote about the wife of Marco Polo, the first journeyer. As far as one knew, no one wrote about the women who were left at home when their husbands were at war or searching for other worlds or traveling out of pure longing. [...Ruth] didn't know that the women gods on all the islands Odysseus visited awaited any traveling sailors around the Mediterranean, to keep them from returning home. (52)

If subversive defamiliarization successfully exposes historical, social and cultural aberrations, it is likely that spiritual realism will as powerfully engage another one of our modern world's cultural ills: disregard for the natural world. One of the novel's central episodes is the whale kill decided upon by the council and in which Thomas and his son Marco take part. From the start the cultural alibi is denounced as self-delusion:

They argued treaty rights, and their return to tradition. Some of the reporters, especially the white men, thought the tribal hunters were men of mystery and spirit, foreign enough to their own America to be right. Yes, to return to their ways would be the right thing. After all America had done to them, they should be given that. When the animal rights activists arrived, the A'atsika men had to decide if they should have them removed by the police or if that would only look worse for their cause. (68)

It is ironic that the tribe's hunters should side with the police, a force usually associated with Euro-American law and order, against the environmentalists. Indigenous environmental knowledge, respect for the animal land and water inhabitants are recurrent themes in Hogan's novels. Concern for endangered species was visible in Mean Spirit, Solar Storms, and Power. In People of the Whale, however, because the men fail to respect the traditional ways-praising the whale, fasting, scrubbing themselves with cedar-the kill turns into a bloody fiasco. The men slaughter a young whale, and Marco is killed (we later learn that he was murdered). Soon after, a storm comes: "That night the breakers rose up and took the whale away. In the morning, to the dismay of the people, it was gone. In the water only the dozer and the winch remained" (100). As the weather conditions worsen, the narrative metaphorically aligns the breaking of the ocean with the breaking of the A'atsika people, for men also can be breakers. 
Then there was the massacre by the Americans seeking gold in the hills and even the babies and elders were bayoneted and shot. There were too few old women left to row and the Americans had burned the canoes so no one could escape. Still some had lived, and gone into the forest and pretended to be trees and thus became invisible, so there are people remaining today. (102)

But the breaking went back further, to the Spanish, the Russians, the British, the teachers and American missionaries, the epidemics in 1910 that killed more than three fourths of the tribe, the enormous whaling boats that nearly brought the whales to extinction. A breaker was not just a wall of crashing water, even though people had spoken of the tsunami and collapsing earth walls. (106)

Ominous signs of meteorological disorder appear: words like "storm," "tsunami," "breakers," "drought" start overrunning the text. "For every action there is a reaction," (105) Ruth thinks, and Feather, the elder, prophesies: "Mark my words. There's going to be a drought. A wrong thing was done. Maybe more than one wrong thing. There will be a drought," the old man warned Ruth. "Get ready for it. N'a sina" (108). These are the concluding lines of Part One.

The textual ecology of give-and-take, respect-and-offense, action-andretaliation makes it clear that Nature has its own ways of manifesting itself-of talking back. As predicted, the drought begins. There are long days of sunlight; "the moon no longer pulls water back" (124); the sea is too warm, and nets remain empty. Finally, the people have to leave.

For a day or two in the terrible new smell of the place of the receding sea, the drying seaweed, there is a caravan of leavers, some honking at others as if the reserve is a large city.

As for Ruth, it seems to her that the wide sea is holding breath, waiting for something, calling for something. (127)

They think about the whale and what they've done, who they have become in time, each person examining their own world. They do not feel the spirits that once lived in the fogs and clouds around them. The alive world is unfelt. They feel abandoned. (128)

Ruth remembers the old stories about the Rain Priest, the man that was once called when the signing of the treaty caused the old drought (130). A sacrifice is needed and Ruth, although she has lost so much already, is willing to pay. When the Rain Priest arrives into town no one recognizes him. He has good looks, long legs, a pony tail: a Jesus-like Rain Priest. He takes Ruth's boat away (that is her sacrifice), and mysteriously, the rain starts falling and the ocean returns. The moment is one of revelation for the people, whose sense of identity and belonging is also restored: "The rain, through flooding, has returned the 
past to the people [...] the past is still with them. They feel beauty again" (153154). Revelation about who the Rain Priest really is is also experienced by the reader when old fisherman Vince comes into the café, saying that he has found Ruth's boat, stranded in the middle of the water: "I saw an octopus climbing down out of it as I approached. I said to myself how strange it was, because it was so large and everyone knows how they hate boats, and yet I swear it looked straight at me like it wanted to be seen" (155).

Spiritual realism, we realize, is a powerful tool to restore nature as a living interlocutor in the dialogue between man and nature-an acting and speaking protagonist in its own right, who can at times turn into a violent antagonist. Hogan's spiritual realism invests the literary vindication of environmental integrity in a holistic way. Cultural integrity and environmental integrity are conceived of as indissociable: traditional practices are based on respect for other-than-human nature, while nature, thus respected and preserved, brings self-respect and well-being to the society of women and men.

If we want to make this literary investigation complete, we probably need to also ask what it means for a writer to elect spiritual realism as her or his preferred literary mode, and how, ultimately, reading spiritual realism impacts readerly habits and competence. Unlike magical realism, spiritual realism, as we have suggested, involves more than just style; it proceeds from some deeper engagement with the natural world. Yet, in his essay, "Magical Realism in Spanish American Literature," (1967) Luis Leal wrote that

Magical realism is, more than anything else, an attitude toward reality that can be expressed in popular or cultured forms, in elaborate or rustic styles, in closed or open structures. What is the attitude of the magical realist toward reality? I have already said that he doesn't create imaginary worlds in which we can hide from everyday reality. In magical realism the writer confronts reality and tries to untangle it, to discover what is mysterious in things, in life, in human acts. (Zamora, Faris 121)

We see that magical and spiritual realisms may overlap as the same dedication to confronting reality can be seen in Hogan's idiosyncratic brand of realism. ${ }^{9}$ Likewise, in 1949, Alejo Carpentier stressed that "To begin with,

9. Unless we are to understand Leal's "confrontation as essentially epistemological and Hogan's as primarily expriential. 
the phenomenon of the marvelous presupposes faith" (Zamora, Faris 86). Both Leal and Carpentier hold that magic is not in the writing but in phenomenal reality. Whereas "magical" realism emphasizes the importance of perception and representation, "magic" realism suggests that reality has something in it that is essentially magic. ${ }^{10}$ Many critics have commented on this distinction, often dichotomized as ontological $v$. phenomenological magic(al) realisms. ${ }^{11}$

When Hogan uses the word "magic," she means the magic of the world, not literary strategy: "the land itself and the magic of it" (Harrison 166). Moreover, she does not mean it in the Euro-American sense of the word, as denoting something extraordinary, but precisely as that which is an integral part of reality and reality's richness. The apparently supernatural elements that stick out in People of the Whale (gill slits and walking octopuses) are only surface devices that betoken a deeper belief in the interconnectedness of all things. It would be wrong however to ignore their poetic function. Books are written for readers to read and ideas to be conveyed. "You have to juggle a lot to be an American Indian writer," says Hogan (Harrison 164). It takes skill, and sometimes unfamiliar techniques, to reach unfamiliar audiences. Perhaps spiritual realism is the best way to bring indigenous knowledge across to wider audiences: spiritual realism, then, as translation. As Hogan explains : "We say the same thing over and over and we're just dismissed. So we have to find new ways to say it. Which is why I find ways to say it in books" (Harrison 171).

Hogan's whales and octopuses are translators that speak to the indigenous readers and help them "decolonize their minds" and "re-indigenize" (Harrison 168). ${ }^{12}$ They also speak to the non-indigenous readers to perhaps help them "re-ethnicize." "Everybody," says Hogan, "is indigenous in one way or another,

10. For a succinct presentation of the history and nature of this distinction, see Maggie Ann Bowers' Magic(al) Realism (2004: 2-3).

11. Delineating the development of magic realism in Latin American fiction, Amaryll Chanady brings the dichotomy into focus: "Arturo Uslar Pietri, the Venezuelan author who was perhaps the first person to apply the term magic realism to Latin American fiction, defined the mode in 1948 as a 'poetic divination or poetic negation of reality', in which man is considered 'as a mystery.' His formulation of magic realism differs in several respects from Carpentier's concept of the marvellous real. The latter appears to have an ontological status, since it is supposed to exist in objective reality in the form of magical rites and imposing natural surroundings, while magic realism is clearly a phenomenological concept (man is considered as a mystery), and a literary mode (an -ism)" (Chanady 1986: 52-53).

12. On the recent turn of environmental literature to cetaceans as liminal animals negotiating between the human and non-human worlds, see Jonathan Steinwand's "What the Whales Would Tell Us: Cetacean Communication in Novels by Witi Ihimaera, Linda Hogan, Zakes Mda, and Amitav Ghosh." 
so it's not particular for just American Indian people. Every human being has that. [Most Euro-Americans think] they don't have any roots. But they really do, they just have further to go and more de-educating to do" (Harrison 174).

Hogan's spiritual realist prose is instrumental in predisposing the mind to free itself from its cultural and epistemological bounds and reach the state of extreme awareness and faith alluded to by Carpentier. The unfamiliar reader may feel estranged at first; he may also learn to experience and enjoy the closeness and merging of worlds. ${ }^{13}$ In any case, the experience is likely to foster heightened sensitivity, intuition, and engagement. To approach environmental issues in such disposition constitutes a radical alternative to the more rationalist approaches, a promising alternative which renews not only our relationship with nature but also the relationship of literature with the world around us.

\section{Bibliography}

Adamson, Joni. "Indigenous Literatures, Multinaturalism, and Avatar: The Emergence of Indigenous Cosmopolitics." American Literay History. Vol. 24, No.1 (Spring 2012). 143-162.

Bowers, Maggie Ann. Magic(al) Realism. London, New York: Routledge, 2004.

Carpentier, Alejo. "On the Marvelous Real in America." Magical Realism: Theory, History, Community. Lois Parkinson Zamora and Wendy B. Faris. Eds. Durham, London: Duke UP, 1995. 75-88.

Casteel, Alix. "Dark Wealth in Linda Hogan's Mean Spirit." Studies in American Indian Literatures. Series 2, Vol. 6, No. 3, Linda Hogan: Calling Us Home (Fall 1994). 49-68.

Chanady, Amaryll. "The Origins and Development of Magic Realism in Latin American Fiction." Magic Realism and Canadian Literature: Essays and Stories. Peter Hinchcliffe and Ed Jewinski. Eds. Waterloo (Ontario): U of Waterloo P, 1986. 49-60.

---. Magical Realism and the Fantastic: Resolved Versus Unresolved Antinomy. New York, London: Garland Publishing, 1985.

13 From the perspective of Reader's Response theory, the validity of categories such as magical realism and spiritual realism depends on the reader's degree of acceptance of the text's implied ontology. Rationalist Euro-Americans readers and more "indigenized" readers will construe the same text as magical, and spiritual, realism, respectively. By the time all readers, indigenous and non-indigenous, reach the level of awareness called for by Hogan's (and others') fictions, realism will no longer be "magical." Nor will it be "spiritual": it will only be realism. 
Diamond, Cora. "Eating Meat and Eating People." Animal Rights: Current Debates and New Directions. Cass Sunstein and Martha Nussbaum. Eds. New York: Oxford UP, 2004. 93-107.

FARIs, Wendy B. “Scheherazade's Children: Magical Realism and Postmodern Fiction.” Magical Realism: Theory, History, Community. Lois Parkinson Zamora and Wendy B. Faris. Eds. Durham, London: Duke UP, 1995. 163-190.

Greenwood Baria, Amy. "Linda Hogan's Two Worlds." Studies in American Indian Literatures. Series 2, Vol. 10, No. 4 (Winter 1998). 67-73.

HARrison, Summer. "Sea Level: An Interview with Linda Hogan." Interdisciplinary Studies in Literature and Environment 18.1 (Winter 2011). 161177.

Hogan, Linda. People of the Whale. New York: Norton, 2008.

---. Power. New York: Norton, 1998.

---. "Silencing Tribal Grandmothers: Traditions, Old Values At Heart Of Makah's Clash Over Whaling." Seattle Times. Dec. 15, 1996.

---. Solar Storms. New York: Scribner, 1995.

---. Mean Spirit. New York: Atheneum, 1990.

LEAL, Luis. "Magical Realism in Spanish American Literature." Magical Realism: Theory, History, Community. Lois Parkinson Zamora and Wendy B. Faris. Eds. Durham, London: Duke UP, 1995. 119-124.

Murphy, Patrick. "Women Writers: Spiritual Realism, Ecological Responsibility, and Inhabitation." Journal of Literature, Culture and Media Studies. No.1 (Summer, June 2009). 5-11.

Rushdie, Salman. Midnight's Children. London: Jonathan Cape, 1980.

Stacks, Geoffrey. "A Defiant Cartography: Linda Hogan's Solar Storms." Mosaic (Winnipeg), Vol. 43, No. 1 (March 2010).

STEINWAND, Jonathan. "What the Whales Would Tell Us: Cetacean Communication in Novels by Witi Ihimaera, Linda Hogan, Zakes Mda, and Amitav Ghosh.” Postcolonial Ecologies: Literatures of the Environment. Elizabeth DeLoughrey and George B. Handley. Eds. Oxford, New York: Oxford UP, 2011. 182-199.

Zamora Parkinson, Lois and Wendy B. Faris. Eds. Magical Realism: Theory, History, Community. Durham, London: Duke UP, 1995.

\footnotetext{
Abstract: Most Native American peoples are arguably engaged in a dialogic relationship with the natural world, which they do not perceive as an inanimate "out-there" but as a close relative, Mother Earth, whose inhabitants are all partners in life. Typically, the relationship is one of respect and reciprocity; but tradition is sometimes flouted. Linda Hogan's People of the Whale (2008) is in part a poetic envisionment of cultural alienation, ecological transgression and consequent natural retaliation. When the tradition of give-and-take is violated by some of the A'atsika people, nature has its own way of talking back: tsunami, fire, volcanic eruption, and especially drought, are nature's responses to human offenses.
} 
Is "magic realism" the best term to describe Hogan's fiction? This is the first question that this study means to answer. We shall then see that Hogan's special brand of realism proves a powerful tool to displace habitual oppositions (man v. nature) and expose anthropological-social (male v. female), historical-political (Euro-American v. Native-American), and ecological (respectful whale-hunting v. blind killing) unbalance. Finally, we shall show that by challenging standard polarities, Hogan's uncanny realism effectively promotes the agency and loquacity of nature, ontologically reinstating nature as a living being, and fosters a more empathetic form of reader's response, ultimately conducive to ecological awareness and care.

Keywords : Linda Hogan, magical realism, spiritual realism, Makah people, whaling rights, cultural alienation, tradition and modernity, natura loquens, the Vietnam war, environmental ethics, animals, ecological (dis)harmony, female agency and resilience.

François Gavillon is Associate Professor at the Université de Bretagne Occidentale in western France, where he teaches American literature, civilization, and environmental history. He has published a book on Paul Auster's novels (Paul Auster, Gravité et légèreté de l'écriture, Presses Universitaires de Rennes, 2000). His research and publications have focused for some years on American ecoliterature and ecocriticism. He is the editor of a collection of essays entitled L'invention de la nature (Université de Bretagne Occidentale, 2009). Forthcoming is a volume of essays, Environmental Crisis and Human Costs, François Gavillon and Ufuk Ozdag. Eds.

Résumé : Les peuples indigènes d'Amérique sont réputés entretenir un dialogue avec le monde naturel, qu'ils ne conçoivent pas comme un lieu distinct inanimé, mais comme un parent proche, la Terre Mère, dont les habitants sont tous des partenaires de vie. Souvent, cette relation est vue comme une relation de respect et de réciprocité. Pourtant, la tradition est parfois violée. Le roman de Linda Hogan, People of the Whale, paru en 2008, a pour motifs l'aliénation culturelle d'une communauté indigène, les A'atsika, le mépris de certains de ses membres pour la Mer nourricière, et la façon dont la Nature répond à ces transgressions. Lorsque l'équilibre écologique garanti par la tradition est rompu, la nature a sa manière bien à elle de riposter : tsunami, incendie, éruption volcaniques, ou encore, comme c'est le cas ici, sécheresse.

Le terme de réalisme magique est-il le plus approprié pour décrire le roman de Hogan ? C'est la première question à laquelle cette étude entend répondre. On verra ensuite que le réalisme insolite de Hogan est fort habile à questionner les oppositions habituelles (l'homme/la nature), et à souligner les déséquilibres socio-anthropologiques (homme/femme), historico-politiques (Euro-américains/ peuples indigènes) et écologiques (pêche à la baleine traditionnelle/carnage). Finalement, on verra qu'en déplaçant les polarités traditionnelles, le réalisme très particulier de Hogan est à même de restituer à la nature son caractère agissant et parlant, nature dont le statut d'être vivant est ontologiquement réaffirmé. II permet aussi au lecteur d'aller vers une attitude plus empathique, consciente et responsable face à ce vivant naturel.

Mots-clés : Linda Hogan, réalisme magique, réalisme spirituel, peuple Makah, droits de pêche à la baleine, aliénation culturelle, tradition et modernité, natura loquens, guerre du Vietnam, éthique environnementale, animaux, (dis)harmonie écologique, personnages/narrateurs féminins et résilience.

François Gavillon est Maître de Conférences à l'Université de Bretagne Occidentale, où il enseigne la littérature, la civilisation et l'histoire environnementale des États-Unis. II a publié un livre sur les romans de Paul Auster (Paul Auster, Gravité et légèreté de l'écriture, Presses Universitaires de Rennes, 2000). Sa recherche et ses publications portent depuis plusieurs années sur l'écolittérature et l'écocritique américaines. Il a dirigé la publication d'un recueil d'essais intitulé L'invention de la nature (Université de Bretagne Occidentale, 2009). II co-dirige avec Ufuk Ozdag la publication d'un volume à paraître, Environmental Crisis and Human Costs. 